\title{
Association between HER-2/neu over-expression and clinico-pathologic parameters of breast cancer in northern Malaysia
}

\author{
M Kamil $^{1}$, N Yusuf ${ }^{1}$, I Khalid ${ }^{2}$, R Islam ${ }^{1}$, M Biswas $^{1}$ and H Hashim ${ }^{1}$ \\ (Index words: oestrogen receptors, progesterone receptors, HER-2/neu, breast carcinoma)
}

\begin{abstract}
Background Breast cancer is the commonest cancer affecting women world wide. Breast cancer is a leading cause of cancer related mortality in Asian countries. Management of breast cancer depends on several tumour-related and patient related factors. HER-2/neu over-expression has been associated with a poor prognosis in breast cancer. We assessed HER-2/neu over expression pattern in unselected breast cancer cases in terms of clinico-pathologic parameters to identify any associations between them.
\end{abstract}

Methods Two hundred cases of breast cancer were evaluated at Advanced Medical and Dental Institute and Hospital Kepala Batas from 2002 to 2007. HER-2/neu status was confirmed in breast cancer tissues by immunohistochemistry. Immunohistochemical expression of HER-2/neu was evaluated according to the published scoring guidelines of the 'HercepTest' (Dako, Carpinteria, CA). Data were analysed to identify any association between HER-2/neu and clinico-pathologic parameters.

Results HER-2/neu over expression was found in 63 $(31.5 \%)$ tumours out of 200 . When assessed for various age groups no significant association was found. However, a high percentage (75\%) of over-expression was noted in the 81-85 years age group. No association was found with different racial groups (Malay, Chinese and Indians), with lymph node status or with grade of tumour. However a positive association was observed with oestrogen receptor and progesterone receptor expression.

Conclusion There was no association between HER$2 /$ neu over expression and age, race, lymph node status or tumor grade. However a positive association was found with oestrogen and progesterone receptor status.

\section{Introduction}

Breast cancer remains the commonest malignancy in women in both developed and developing worlds. The lowest incidence is reported from far eastern and south eastern Asian countries [1, 2].

In Malaysia the lack of a cancer registry makes it difficult to know the exact incidence of breast cancer. The International Agency for Research in Cancer reported that there were 3,825 new cases and 1,707 deaths due to breast cancer in year 2000, in Malaysia. The crude incidence was estimated to be 34.9 per 100,000 population [3].

Multiple factors, related to patient and tumour are important in the management of breast cancer as it is regarded as a heterogeneous disease. HER-2/neu overexpression, tumour size, lymph node status, histological grade, mitotic index, oestrogen receptor status, progesterone receptor status, p53 and MIB-1 proliferation index are the prognostic indicators commonly used.

The HER-2 neu gene is located on chromosome $17 q$ which encodes for a trans-membrane tyrosine kinase receptor protein which is a member of the HER family. HER-2 gene amplification is usually noted in 10-34\% of invasive breast carcinomas and it is associated with poor patient survival [5]. A humanised monoclonal antibody, trastuzumab ('Herceptin'), targeting the human epidermal growth factor receptor 2 (HER-2) gene is available for treatment but it is expensive and not used routinely in Malaysia.

Our study was designed to examine the association of other clinico- pathologic markers with HER-2/neu over expression, as it may help the management of breast cancer in Malaysia.

\section{Methods}

This cross sectional study was done at Advanced Medical and Dental Institute and Hospital Kepala Batas (HKB) in Northern Malaysia from 2002 to 2007. HKB is major referral centre for cancer patients. HER-2/neu status was determined in 200 patients with breast cancer by immunohistochemistry (IHC). Immunohistochemical expression of HER-2/neu was evaluated according to the published scoring guidelines of the 'HercepTest' (Dako, Carpinteria, CA). Data were analysed to identify any association between HER-2/neu and clinico-pathologic parameters such as age, race, oestrogen and progesterone receptors, tumour grade and lymph node status. Ethical approval was obtained from Ministry of Health of Malaysia. Data were analysed using SPSS software. Chisquare test and Fisher's exact test were used to assess the association of HER-2/neu expression with other prognostic indicators.

\section{${ }^{1}$ Advanced Medical and Dental Institute, University Sains Malaysia, Penang, Malaysia and ${ }^{2}$ Hospital Seberang Jaya, Penang, Malaysia.}

Correspondence: MK, e-mail <kamilpk2001@yahoo.com>. Received 15 July and accepted 17 November 2009. Competing interests: none declared. 


\section{Results}

HER-2/neu over expression was found in 63 (31.5\%) tumours out of the 200 cases. Although no significant association was found with different age groups (Table 1), a high percentage of patients in age groups 71-80 (58.3\%) and 81-85 (75.0\%) showed HER-2/neu over-expression. No association was found with various racial groups i.e. Malay, Chinese and Indians (Table 2). However there was a trend for Malay (36.5\%) patients to show a higher over expression of HER-2/neu. Lymph node status in 198 analysable cases had no association with HER-2/neu expression (Table 3). There was no association between HER-2/neu with the tumour grade in 196 cases (Table 4). However a positive association was observed with expression of oestrogen receptor status (ER) and progesterone receptor status (PR) (Tables 5 and 6).

Table 1. Association of HER2/neu with various groups age groups

\begin{tabular}{lcclc}
\hline $\begin{array}{l}\text { Age } \\
\text { group (years) }\end{array}$ & $n$ & $\begin{array}{c}\text { HER2neu } \\
\text { positive } \\
\text { freq (\%) }\end{array}$ & $\begin{array}{c}\text { HER2neu } \\
\text { negative }\end{array}$ & $p$ value $^{a}$ \\
\hline $28-40$ & 33 & $11(33.3 \%)$ & $22(66.6 \%)$ & \\
$41-50$ & 56 & $13(23.2 \%)$ & $43(76.8 \%)$ & 0.069 \\
$51-60$ & 62 & $20(32.2 \%)$ & $42(67.7 \%)$ & \\
$61-70$ & 33 & $08(24.2 \%)$ & $25(75.7 \%)$ & \\
$71-80$ & 12 & $07(58.3 \%)$ & $05(41.7 \%)$ & \\
$81-85$ & 04 & $03(75.0 \%)$ & $01(25.0 \%)$ & \\
Total & 200 & $62(31.0 \%)$ & $138(69.0 \%)$ & \\
\hline
\end{tabular}

${ }^{a}$ Fisher's Exact test

Table 2. Association of HER2/neu with race

\begin{tabular}{lccccc}
\hline Race & $n$ & $\begin{array}{c}\text { HER2neu positive } \\
\text { freq (\%) }\end{array}$ & $\begin{array}{c}\text { HER2neu negative } \\
\text { freq (\%) }\end{array}$ & $\begin{array}{c}\chi^{2} \\
(d f)\end{array}$ & $p$ value \\
\hline Malay & 93 & $34(36.5 \%)$ & $59(63.4 \%)$ & $4.389(2)$ & 0.111 \\
Chinese & 85 & $26(30.5 \%)$ & $59(69.5 \%)$ & \\
Indian & 22 & $03(13.6 \%)$ & $19(86.3 \%)$ & \\
Total & 200 & $63(31.5 \%)$ & $137(68.5 \%)$ & \\
\end{tabular}

${ }^{a}$ Chi-square test for independence 
Table 3. Association of HER2 Ineu with lymph node status

\begin{tabular}{lcllcc}
\hline Lymph node status & $n$ & $\begin{array}{c}\text { HER2neu } \\
\text { positive } \\
\text { freq (\%) }\end{array}$ & $\begin{array}{c}\text { HER2neu } \\
\text { negative } \\
\text { freq (\%) }\end{array}$ & $\begin{array}{c}\chi^{2} \\
(d f)\end{array}$ & $p$ value \\
\hline Positive & 78 & $26(33.3 \%)$ & $52(66.6 \%)$ & $0.244(1)$ & 0.621 \\
Negative & 120 & $36(30 \%)$ & $84(70 \%)$ & & \\
Total & 198 & $62(31.3 \%)$ & $136(68.6 \%)$ & \\
\hline
\end{tabular}

${ }^{a}$ Chi-square test for independence

Table 4. Association of HER2/neu with tumour grade

\begin{tabular}{lccccc}
\hline Tumor Grade & $n$ & $\begin{array}{c}\text { HER2neu } \\
\text { positive } \\
\text { freq (\%) }\end{array}$ & $\begin{array}{c}\text { HER2neu } \\
\text { negative } \\
\text { freq (\%) }\end{array}$ & $\begin{array}{c}\chi^{2} \\
(d f)\end{array}$ & $p$ value \\
\hline Grade I & 43 & $15(34.8 \%)$ & $28(65.1 \%)$ & $0.756(2)$ & 0.685 \\
Grade II & 85 & $27(31.3 \%)$ & $58(67.4 \%)$ & & \\
Grade III & 66 & $18(28.8 \%)$ & $48(71.6 \%)$ & $134(68.3 \%)$ \\
Total & 194 & $60(30.6 \%)$ & & \\
\hline
\end{tabular}

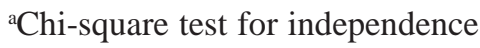

Table 5. Association of HER2/neu with oestrogen receptor expression

\begin{tabular}{lccccc}
\hline $\begin{array}{l}\text { Oestrogen } \\
\text { receptors }\end{array}$ & $n$ & $\begin{array}{c}\text { HER2neu } \\
\text { positive } \\
\text { freq (\%) }\end{array}$ & $\begin{array}{c}\text { HER2neu } \\
\text { negative } \\
\text { freq (\%) }\end{array}$ & $\begin{array}{c}\chi^{2} \\
(d f)\end{array}$ & $p$ value \\
\hline Positive & 62 & $28(45.1 \%)$ & $34(54.8 \%)$ & $5.983(1)$ & 0.014 \\
Negative & 128 & $35(27.3 \%)$ & $93(72.6 \%)$ & & \\
Total & 190 & $63(33.1 \%)$ & $127(66.8 \%)$ & \\
\hline
\end{tabular}

${ }^{\text {a }}$ Chi-square test for independence

Table 6. Association of HER2/neu with progesterone receptor expression

\begin{tabular}{lccccc}
\hline $\begin{array}{l}\text { Progesterone } \\
\text { receptors }\end{array}$ & $n$ & $\begin{array}{c}\text { HER2neu } \\
\text { positive } \\
\text { freq (\%) }\end{array}$ & $\begin{array}{c}\text { HER2neu } \\
\text { negative } \\
\text { freq (\%) }\end{array}$ & $\begin{array}{c}\chi^{2} \\
(d f)\end{array}$ & $p$ value $^{\mathrm{a}}$ \\
\hline Positive & 60 & $26(43.3 \%)$ & $34(56.6 \%)$ & $6.422(1)$ & 0.011 \\
Negative & 135 & $34(25.1 \%)$ & $101(74.8 \%)$ & & \\
Total & 195 & $60(30.7 \%)$ & $135(69.2 \%)$ & \\
\hline
\end{tabular}

${ }^{a}$ Chi-square test for independence 


\section{Discussion}

Breast cancer is the leading cancer among Malaysian women. The commonest age group affected is 40 to 49 years. The median age is 50 years. The average size of the tumour is $5.4 \mathrm{~cm}$ in diameter at presentation. Malay women appear to have larger tumours and an advanced stage at presentation than other ethnic groups (i.e. Chinese and Indian). More than half the tumours are in stage 3 and stage 4 [6].

As breast cancer management requires consideration of several tumour-related factors, their correlation with other prognostic factors is important for clinicians. It is agreed in general that tumour size, number of lymph nodes involved and tumor grade are still the most powerful predictors of prognosis. During the recent years over expression of HER-2/neu has provided another target for treatment of breast cancer using monoclonal antibodies. This increases the sensitivity of tumour cells to undergo apoptosis [7].

Immunohistochemistry and fluorescence in-situ hybridization (FISH) are currently the most commonly employed assays for determining HER-2 status in the clinical setting. Overall HER-2/neu expression in our study was around $31 \%$, which is comparable to Western figures [8]. HER-2 over-expression is $18.1 \%$ in Tunisian patients with breast carcinoma [9]. In Pakistan it is reported to be $31 \%[10]$.

No association was found with age, race, and lymph node status and tumour grade in this study. Other studies done in Asia also showed no association between HER-2 over expression and other prognostic factors except few studies which showed an association with the tumour grade $[8,9,15,16]$.

Lymph node metastases are an important prognostic parameter. So far association of lymph node metastases and HER-2 positivity has shown variable results. Some studies $[8,11,12]$ have demonstrated a positive association between HER-2/neu expression and lymph node metastasis, though no association was found in our study and in some of the Western studies [13, 14]. This may be due to the different biological behaviour of the tumours belonging to different ethnic groups in Malaysia.

Oestrogen and progesterone receptors form an important part of breast cancer management. Oestrogen and progesterone receptor examination is recommended for prediction of response to hormonal treatment. Diseasefree and overall survival decrease with less receptors in most cases. However some studies have shown that ER positive patients showed poor prognosis similar to ER negative patients $[17,18]$. An interesting phenomenon has been observed with co expression of HER-2/neu with oestrogen receptors. Tumours with positive ER and HER2/neu do not response to tamoxifen treatment due to interaction of tyrosine kinase pathway with hormonal pathway [19].
Our study showed a positive association of HER-2/ neu with ER expression which reached statistical significance. This is in contradiction to most studies. Some reported no correlation of ER and PR with HER-2/neu [20]. An inverse association between ER and PR with HER-2/ neu has been observed by others [10, 13, 14].

In our study, ER negativity was more strongly associated with HER-2/neu negativity. It was the same with PR negativity. However our study has some limitations. Malaysian population represent a multiracial community with Chinese, Malays and Indians as major racial groups and this biological diversity may be responsible for differences in ER, PR and HER-2/neu expression. Furthermore our results may have been affected by the use of immuno histochemistry analysis of HER-2/neu. Therefore more studies are needed from Malaysia to verify our findings.

\section{References}

1. Lacey JV J, Devesa SS, Brinton LA. Recent trends in breast cancer incidence and mortality. Environmental and Molecular Mutagenesis 2002; 39: 82.

2. Shibuya K, Mathers CD, Boschi-Pinto C, et al. Global and regional estimates of cancer mortality and incidence by site. BMC Cancer 2002; 2: 37.

3. Ferlay J, Bray F, Pisani P, Parkin DM. Cancer Incidence, Mortality and Prevalence Worldwide, Version 1.0 IARC Cancer Base No.5. Lyon: IARC Press, 2001.

4. Teguh A, Harijadi, S. Hormone receptor status of operable breast cancers in Indonesia: correlation with other prognostic factors and survival. Asian Pacific Journal of Cancer Prevention 2006; 7: 321-4.

5. Ross JS, Fletcher JA, et al. The HER-2/neu gene and protein in breast cancer biomarker and target of therapy. Oncologist 2003; 8: 307-25.

6. Hisham AN, Yip CH. Overview of breast cancer in Malaysian women: A problem with late diagnosis. Asian Journal of Surgery 2004; 27: 130-3.

7. Park JW, Neve RM, Szollosi J, Benz CC. Unraveling the biologic and clinical complexities of HER-2. Clinical Breast Cancer 2008; 8: 392- 401.

8. Lal P, Tan LK, Chen B. Correlation of HER-2 status with estrogen and progesterone receptors and histologic features in 3,655 invasive breast carcinomas. American Journal of Clinical Pathology 2005; 123: 541-6.

9. Ayadi L, Khabir A, Amouri A, Karray S, et al. Correlation of HER-2 over expression with clinico-pathological parameters in Tunisian breast carcinoma. World Journal Surgical Oncology 2008; 6: 112.

10. Sharif MA, Mamoon N, Mushtaq A, Khadim MT. Morphological profile and association of HER-2/Neu with prognostic markers in breast carcinoma in Northern Pakistan. Journal of the College of Physicians and Surgeons Pakistan 2009; 9: 99-103. 
11. Aryandono T, Harijadi, Ghozali A. Correlation of clinical, pathological status, hormone receptor and c-erbB-2 oncoprotein in breast cancer patients. Annals of Oncology 2005; 16: 1755-61.

12. Traina A, Agostara B, Marasà L, et al. HER-2/neu expression in relation to clinicopathologic features of breast cancer patients. Annals of New York Academy of Science 2006; 1089:159-67.

13. Almasri NM, Al-Hamad M. Immunohistochemical evaluation of human epidermal growth factor receptor 2 and estrogen and progesterone receptors in breast carcinoma in Jordan. Breast Cancer Research 2006; 7: 598-604.

14. Huang HJ, Neven P, Drijkoningen M, et al. Association between tumour characteristics and HER-2/neu by immunohistochemistry in 1362 women with primary operable breast cancer. Journal of Clinical Pathology 2005; 58: 611-6.

15. Rilke F, Colnaghi MI, Cascinelli N, et al. Prognostic significance of HER-2/neu expression in breast cancer and its relationship to other prognostic factors. International Journal of Cancer 1991; 49: 44-9.
16. Hoff ER, Tubbs RR, Myles JL, Procop GW. HER-2/neu amplification in breast cancer: stratification by tumor type and grade. American Journal of Clinical Pathology 2002; 117: $916-21$.

17. Clark GM. Prognostic and Predictive Factors. In: Harris JR, Lippmann ME, Morrow M, Osborne CK(eds).Diseases of the Breast. 2nd ed, Lippincott, Williams \& Wilkins, Philadelphia. 2000: 489-514.

18. Trudeau ME, Pritchard KI, Chapman JAW, et al. Prognostic factors affecting the natural history of node-negative breast cancer. Breast Cancer Research and Treatment 2005; 89: 35-45.

19. Dowsett M. Over expression of HER-2 as a resistance mechanism to hormonal therapy for breast cancer. Endocrine-Related Cancer 2001; 8: 191-5.

20. Aryandono T, Harijadi, S. Hormone receptor status of operable breast cancers in Indonesia: Correlation with other prognostic factors and survival. Asian Pacific Journal of Cancer Prevention 2006; 7: 321-4. 